\title{
Photodynamic enhancement of the activity of antibiotics used in urinary tract infections
}

\author{
Dorota Tichaczek-Goska $^{1} \cdot$ Dorota Wojnicz $^{1}$ (I) $\cdot$ Krzysztof Symonowicz $^{2} \cdot$ Piotr Ziółkowski $^{2} \cdot$ Andrzej B. Hendrich $^{1}$
}

Received: 29 October 2018 / Accepted: 21 January 2019 /Published online: 26 February 2019

(C) The Author(s) 2019

\begin{abstract}
Photodynamic therapy (PDT) has been proven to kill different microbial cells. However, to our knowledge, none of the available reports describes the modulatory effect of this therapy on the antibacterial activity of antibiotics against Escherichia coli rods being the main causative agent of urinary tract infections (UTIs). Therefore, the aim of our study was to verify if the PDT can enhance the antibacterial activity of antibiotics recommended in the treatment of UTIs. An attempt to determine the optimal conditions of PDT to enhance the bactericidal activity of ciprofloxacin, amikacin, and colistin has been made. In order to find the optimal antimicrobial conditions, the efficacy of four protocols associated with the use of different energy doses (70 and $120 \mathrm{~J} /$ $\left.\mathrm{cm}^{2}\right)$ and chlorin e6 (Ce6) concentrations $(50$ and $100 \mu \mathrm{g} / \mathrm{mL})$ has been verified. The antibacterial effect of combined PDT and antibiotics was assessed by the time-kill assay. The best results were achieved for Ce6 at a concentration of $100 \mu \mathrm{g} / \mathrm{mL}$ and the energy dose $120 \mathrm{~J} / \mathrm{cm}^{2}$ for bacterial suspensions treated with ciprofloxacin. Taken together, our results showed that PDT using Ce6 improves the antibacterial activity of antibiotics effectively inhibiting bacterial growth and being promising in the elimination of bacterial UTIs in humans.
\end{abstract}

Keywords Antimicrobial photodynamic therapy (aPDT) · Chlorin e6 · Ciprofloxacin · Colistin · Amikacin · Uropathogenic Escherichia coli

\section{Introduction}

Escherichia coli is the most prevalent gram-negative agent causing urinary tract infections (UTIs) [1]. The increasing number of recurrent and chronic UTIs [2, 3] and extensive use of antibiotics leading to the selection of multi-drugresistant bacterial strains underlines the urgent need for the further discovery and improvement of alternative ways of microorganisms inactivation $[4,5]$. For years, antimicrobial photodynamic therapy (aPDT) has been used effectively in the eradication of gram-positive and gram-negative bacteria $[6$, 7]. Various bacterial cells' structures and components are the targets for PDT in contrast to one major target in the case of

Dorota Wojnicz

dorota.wojnicz@umed.wroc.pl

1 Department of Biology and Medical Parasitology, Wrocław Medical University, Mikulicza-Radeckiego 9, 50-367 Wrocław, Poland

2 Department of Pathomorphology, Wrocław Medical University, Marcinkowskiego 1, 50-368 Wrocław, Poland antibiotics $[8,9]$. Thus, PDT reduces the risk of developing resistance of microorganisms exposed to it [10].

Chlorin e6 ( $\mathrm{Ce} 6)$ is a second-generation photosensitizer used in PDT. It has been reported to possess noteworthy advantages, e.g., short photosensitizing period, selective accumulation in the target tissue and cell's parts, relatively good absorption of red light, and minimal side effects [11, 12]. The combination of the aPDT and conventionally used antibiotics to treat severe bacterial infections shows significant potential, being a chance for more effective therapies also in UTIs [7, 13, 14].

According to the European Association of Urology guidelines on urological infections, ciprofloxacin and amikacin are recommended for empirical antimicrobial therapy in pyelonephritis [15]. The increase of antibiotic resistance in gramnegative bacteria has resurrected the importance of polymyxin antibiotics. Colistin, being polymyxin $\mathrm{E}$, is a last-resort antibiotic very often used against multi-drug-resistant Enterobacteriaceae strains causing multiple infections and, among others, UTIs [16-19]. All three, ciprofloxacin, amikacin, and colistin, are well-known antimicrobials belonging to different groups of antibiotics. Amikacin (AN) is an 
aminoglycoside antibiotic which acts by binding to the bacterial 30S ribosomal subunit and inhibiting in this way protein synthesis. Ciprofloxacin (CIP) belongs to fluoroquinolones. It inhibits the bacterial enzyme DNA gyrase and prevents replication of bacterial DNA during bacterial growth and reproduction. Colistin (CL) is an antibiotic belonging to cyclic cationic polypeptides. Thanks to its amphiphilic nature, CL can easily penetrate into the bacterial cell and integrate with the cell membrane phospholipids thus disrupting the cell's structure [9]. It is well-known that the use of antibiotics for a long time is undesirable in clinical practice due to their adverse effects on the bacteria inducing multi-drug resistance. For that reason, it is very important to find more effective therapeutic methods preventing this disquieting phenomenon. aPDT seems to be such a method.

For the reasons presented shortly above, the aim of our study was to evaluate if aPDT can enhance the activity of antibiotics recommended in UTI treatment.

\section{Material and methods}

\section{Bacteria}

Uropathogenic Escherichia coli strain (UPEC060) came from the collection of clinical bacterial isolates of the Department of Biology and Medical Parasitology, the Wrocław Medical University, Poland. The strain was maintained on slopes containing nutrient broth and glycerol in a final concentration of $40 \%$, stored at $-20{ }^{\circ} \mathrm{C}$.

\section{Photosensitizer and light source}

Chlorin e6 (Ce6) was purchased from Frontier Scientific (Porphyrin Products, Logan, USA) and dissolved in DMSO and sterile water $(1: 1)$ to obtain a stock concentration of $500 \mu \mathrm{g} / \mathrm{mL}$. Finally, the Ce6 concentrations of $50 \mu \mathrm{g} / \mathrm{mL}$ and $100 \mu \mathrm{g} / \mathrm{mL}$ were then used to measure photodynamic efficiency against $E$. coli strain. As a light source, a diode laser LASER COUPLER 635 (Wroclaw, Poland) has been used to irradiate $\mathrm{Ce} 6$ at the wavelength $635 \mathrm{~nm}$, at the power density of $0.29 \mathrm{~W} / \mathrm{cm}^{2}$, and at the total energy density of $70 \mathrm{~J} / \mathrm{cm}^{2}$ or $120 \mathrm{~J} / \mathrm{cm}^{2}$, with no thermal side effects.

\section{Antibiotics}

Three antimicrobial agents with different bacterial cell targets were used in this study: colistin sodium methanesulfonate (CL; Colistin ${ }^{\circledR}$, Polfa Tarchomin S.A., Warsaw, Poland), ciprofloxacin lactate (CIP; Proxacin ${ }^{\circledR}$, Polfa S.A., Warsaw, Poland), and amikacin disulfate salt (AN; Biodacyna ${ }^{\circledR}$, BIOTON S.A., Warsaw, Poland).

\section{MIC determination}

Minimum inhibitory concentrations (MICs) of antibiotics were performed in Mueller-Hinton broth (MHB; Emapol, Gdansk, Poland) according to CLSI guidelines for broth microdilution susceptibility testing [20]. In the current study, the MICs of CL, CIP, and AN were $0.5 \mu \mathrm{g} / \mathrm{mL}, 0.0039 \mu \mathrm{g} /$ $\mathrm{mL}$, and $1.0 \mu \mathrm{g} / \mathrm{mL}$, respectively. Subinhibitory concentration $(0.5 \times$ MIC $)$ of each antibiotic was then used in the experiments.

\section{Bacterial culture conditions used in aPDT experiments}

The bacteria were grown overnight at $37^{\circ} \mathrm{C}$ in the presence of $0.5 \times$ MICs of each antibiotic. Next, bacteria were harvested by centrifugation ( $4000 \mathrm{rpm} / 20 \mathrm{~min}$ ) and resuspended in PBS to reach a final concentration of $1-2 \times 10^{8} \mathrm{CFU} / \mathrm{mL}(0.5$ McFarland). The control sample contained no antibiotic.

\section{aPDT experimental conditions}

The work steps of the experimental study are shown in Fig. 1. We used the experimental groups treated with $(i)$ antibiotic (CL, AN, or CIP); (ii) Ce6 and red laser light (L); (iii) antibiotic and light $(\mathrm{CL}+\mathrm{L}, \mathrm{AN}+\mathrm{L}, \mathrm{CIP}+\mathrm{L})$ and the sample containing bacteria treated with no antibiotic nor light (control).

Cultured overnight bacterial suspensions $\left(1-2 \times 10^{8} \mathrm{CFU} /\right.$ $\mathrm{mL}$ ) were plated to the wells of a 96-well plate. Then, MHB and $\mathrm{Ce} 6$ stock solutions were also added to the wells to obtain the final concentrations of Ce6 $(50 \mu \mathrm{g} / \mathrm{mL}$ or $100 \mu \mathrm{g} / \mathrm{mL})$. The plate was incubated for $15 \mathrm{~min}$ at room temperature (in the dark) before exposure to the red light at $70 \mathrm{~J} / \mathrm{cm}^{2}$ or $120 \mathrm{~J} /$ $\mathrm{cm}^{2}$. PDT parameters were used in four combination protocols: $50 \mu \mathrm{g} / \mathrm{mL}+70 \mathrm{~J} / \mathrm{cm}^{2} ; 50 \mu \mathrm{g} / \mathrm{mL}+120 \mathrm{~J} / \mathrm{cm}^{2} ; 100 \mu \mathrm{g} /$ $\mathrm{mL}+70 \mathrm{~J} / \mathrm{cm}^{2} ; 100 \mu \mathrm{g} / \mathrm{mL}+120 \mathrm{~J} / \mathrm{cm}^{2}$.

Then, samples were diluted and cultured in triplicate on nutrient agar plates (Biomed, Poland) immediately $\left(t_{0}\right)$, at $1 \mathrm{~h}\left(t_{1}\right)$, and $3 \mathrm{~h}\left(t_{3}\right)$ after irradiation. Agar plates were incubated at $37^{\circ} \mathrm{C}$ for $24 \mathrm{~h}$ and the number of colony-forming units per milliliter was counted (Fig. 1).

\section{Statistical analysis}

The results are given as a mean value from three separate experiments. All values were expressed as a mean $\pm \mathrm{SD}$. The differences in the growth of bacteria exposed to different combinations of agents: antibiotics/Ce6/light and unexposed bacteria were analyzed by the parametric $t$ test for independent samples. Statistical calculations were made using Statistica 13.1 (Stat Soft, Kraków, Poland). $P$ values $<0.05$ were considered to be statistically significant. 


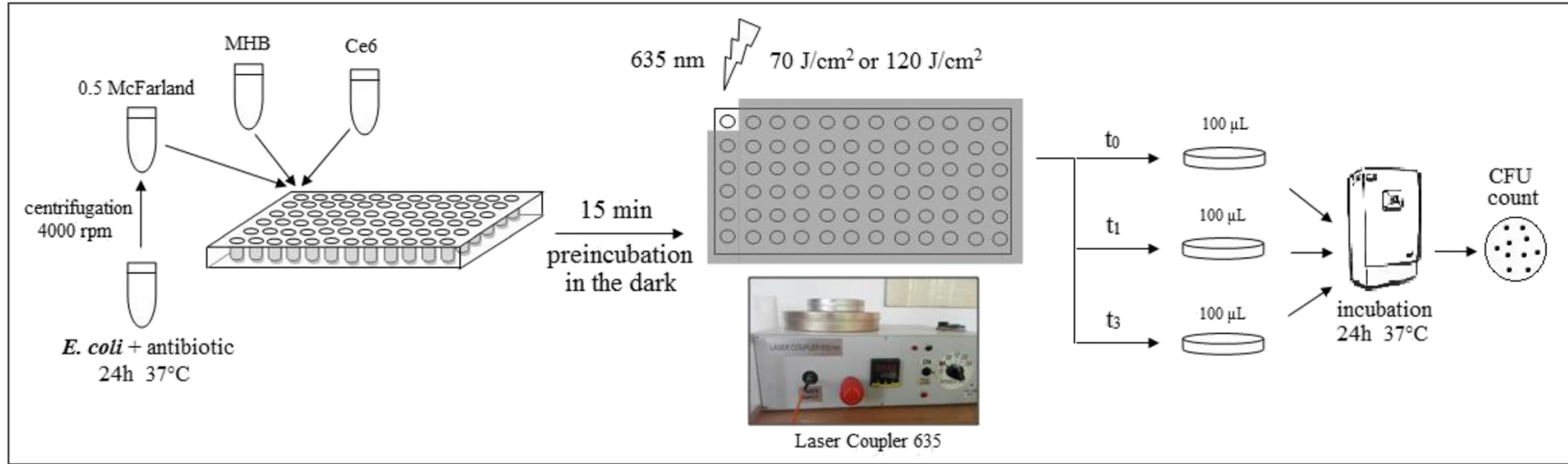

Fig. 1 Scheme demonstrating the flow of experiments

\section{Results}

The preliminary study (data not shown) showed no statistically significant changes in bacterial survival when UTI060 was treated with (1) Ce6 in the dark, (2) antibiotic and Ce6 in the dark, (3) light without Ce6, and (4) antibiotic and light without $\mathrm{Ce} 6$ in comparison to the control sample containing untreated bacteria.

In further experiments, the impact of aPDT on the bacteria incubated overnight in the presence of $0.5 \times$ MIC of antibiotics (CL, AN, CIP) and untreated bacteria (no antibiotics nor light) has been determined. In the experiments, $\mathrm{Ce} 6$ at concentrations of $50 \mu \mathrm{g} / \mathrm{mL}$ and $100 \mu \mathrm{g} / \mathrm{mL}$, and a light dose of $70 \mathrm{~J} /$ $\mathrm{cm}^{2}$ and $120 \mathrm{~J} / \mathrm{cm}^{2}$ in four different combinations as described in the "Material and methods" section was used to find optimal conditions of PDT modulating the activity of antibiotics.

The results of bacterial survival in the presence of Ce6 at a concentration of $50 \mu \mathrm{g} / \mathrm{mL}$ and light dose $70 \mathrm{~J} / \mathrm{cm}^{2}$ are shown visually in Fig. 2. The number of colonies (CFU/mL) of bacteria incubated overnight in antibiotics and then irradiated decreased in comparison to the number of colonies of bacteria unsubjected to PDT. However, the statistically significant decrease of viable bacteria was observed only at $t_{0}$ and $t_{1}$ in the case of rods treated with CL and CIP $(p<0.05)$. The greatest reduction of the colony number was noticed at $t_{0}$ for $E$. coli incubated with CIP, comparable to the nonirradiated bacteria. The colony-forming units per milliliter decreased 3.8 times, from $8.3 \times 10^{7}$ to $2.2 \times 10^{7}$, respectively.

The increase of Ce6 concentration from 50 to $100 \mu \mathrm{g} / \mathrm{mL}$ and illumination of the bacterial suspensions with a total energy dose of $70 \mathrm{~J} / \mathrm{cm}^{2}$ caused the statistically significant decrease of bacterial survival at $t_{0}$ in the case of all antibiotics and $t_{1}$ for bacteria treated with CL and CIP $(p<0.05)$ (Fig. 3). The greatest reduction of the colony number was also noticed at $t_{0}$ for rods incubated with CIP. The colony number decreased by 2.7 times, from $8.4 \times 10^{7} \mathrm{CFU} / \mathrm{mL}$ in the control to $3.1 \times 10^{7} \mathrm{CFU} / \mathrm{mL}$ in the illuminated sample (Fig. 3).

Figure 4 shows the results of bacterial survival in the presence of $\mathrm{Ce} 6$ at a concentration of $50 \mu \mathrm{g} / \mathrm{mL}$ irradiated with light of the total energy dose increased from 70 to $120 \mathrm{~J} / \mathrm{cm}^{2}$. Such experimental conditions caused a significant reduction of bacterial survival in all examined samples at $t_{0}$ and $t_{1}$ $(p<0.05)$. At $t_{0}$, the greatest reduction of colony-forming units per milliliter (4.2 times from $8.3 \times 10^{7}$ to $1.9 \times 10^{7}$ ) was noticed in the sample treated with CIP. While at time $t_{1}$, the concentration of viable bacteria decreased the most in the case of $E$. coli incubated with AN. The colony-forming units per milliliter was reduced from $1.6 \times 10^{8}$ in the control sample to $5.2 \times 10^{7}$ in the examined one.

Simultaneous use of the high-energy dose $\left(120 \mathrm{~J} / \mathrm{cm}^{2}\right)$ and Ce6 concentration $(100 \mu \mathrm{g} / \mathrm{mL})$ caused a significant reduction of bacterial viability at $t_{0}, t_{1}$, and $t_{3}(p<0.05)$ (Fig.5). Although the most profound effect of synergy between all antibiotics and PDT was noticed at $t_{1}$. The number of colony-forming units per milliliter was reduced 3.3 times for CL, 4.0 times for AN, and 4.9 times in case of CIP.

\section{Discussion}

PDT is a method widely used in dermatology and periodontics, less frequently in ophthalmology, gastroenterology, or other medicine branches [21-24]. This method is also successfully used against gram-positive and gram-negative bacteria in in vitro studies [25-31]. However, it should be underlined that there are only a few reports describing the use of aPDT in urological infection [13, 14]. To our knowledge, current work is the first report focused on the modulatory effect of the aPDT on antibacterial activity of antibiotics possessing different mechanisms of action against UPEC rods. The UPEC060 strain used in our study was genetically characterized previously and classified to phylogenetic group B2 [32]. The Ce6 used in this study is structurally closely related to porphyrins but with a higher degree of saturation of the ring system [33]. It is worth noticing that the main advantages of $\mathrm{Ce} 6$ are low toxicity, fast and sufficiently selective accumulation in the target tissue, and higher photosensitizing efficacy than porphyrins $[6,33]$. Since different protocols concerning Ce6 

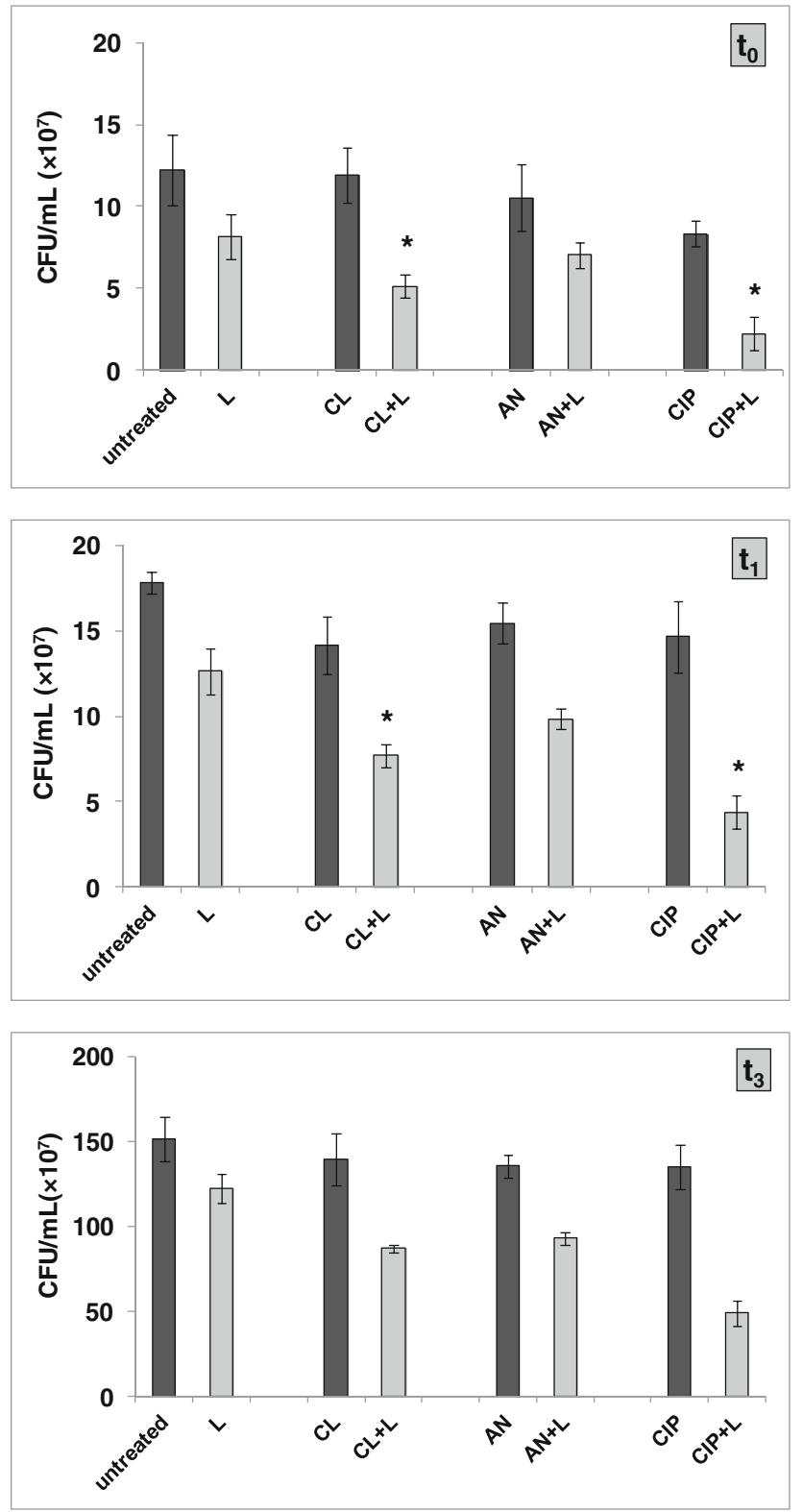

Fig. 2 Effect of PDT (Ce6 $50 \mu \mathrm{g} / \mathrm{mL}$; energy dose $70 \mathrm{~J} / \mathrm{cm}^{2}$ ) on the survival of Escherichia coli treated with antibiotics. Untreated, no antibiotic, no irradiation; L, light; CL, colistin; AN, amikacin; CIP, ciprofloxacin. Values represent the mean $\pm \mathrm{SD}$ of three separate experiments. The asterisk indicates a statistically significant result $(p<0.05)$

concentration and/or light energy were used in experiments performed by other research groups [34,35], we examined few Ce6/light combinations to find the most effective one. As described in the "Material and methods" section, the efficacy of four protocols (combining the values given in $[34,35]$ ) associated with the use of different energy doses (70 and $120 \mathrm{~J} / \mathrm{cm}^{2}$ ) and $\mathrm{Ce}_{6}$ concentrations (50 and $100 \mu \mathrm{g} / \mathrm{mL}$ ) has been verified.

In our study, the representative members (CIP, CL, $\mathrm{AN}$ ) of the three major classes of antibiotics have been
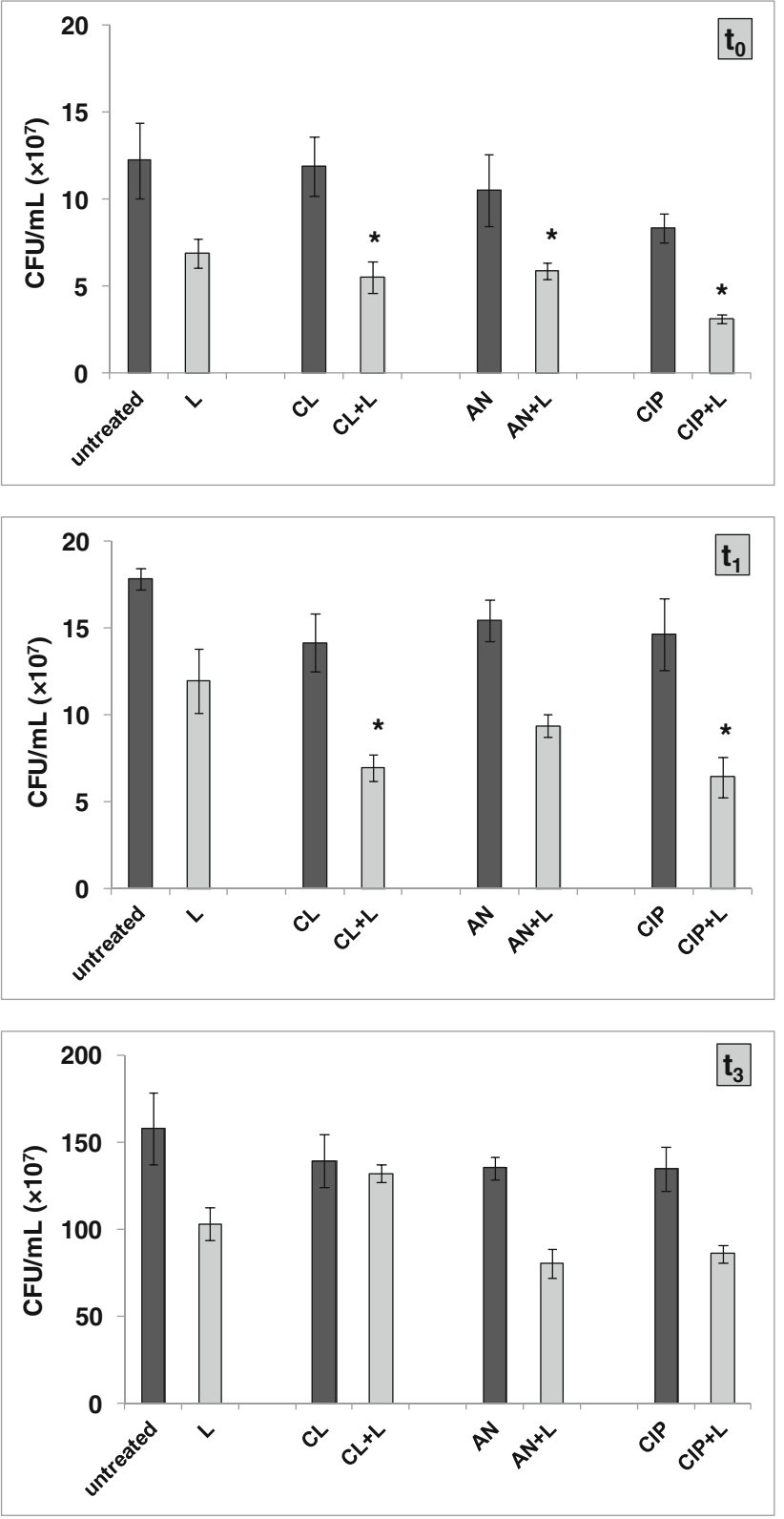

Fig. 3 Effect of PDT (Ce6 $100 \mu \mathrm{g} / \mathrm{mL}$; energy dose $70 \mathrm{~J} / \mathrm{cm}^{2}$ ) on the survival of Escherichia coli treated with antibiotics. Untreated, no antibiotic, no irradiation; L, light; CL, colistin; AN, amikacin; CIP, ciprofloxacin. Values represent the mean $\pm \mathrm{SD}$ of three separate experiments. The asterisk indicates a statistically significant result $(p<0.05)$

used. Despite the fact that the in vivo therapeutic result of treatment is the best when the antibiotic concentration between consecutive doses is above the MIC, we used the sub-lethal doses of the antimicrobials. Looking at the pharmacokinetic curves of antibiotics, it can be seen that their concentrations exceed the MIC values for only a certain period of time. Then, they become lower than the MIC especially in tissues, i.e., the sites of infections where antibiotic concentrations are frequently lower than those in the blood [36]. 

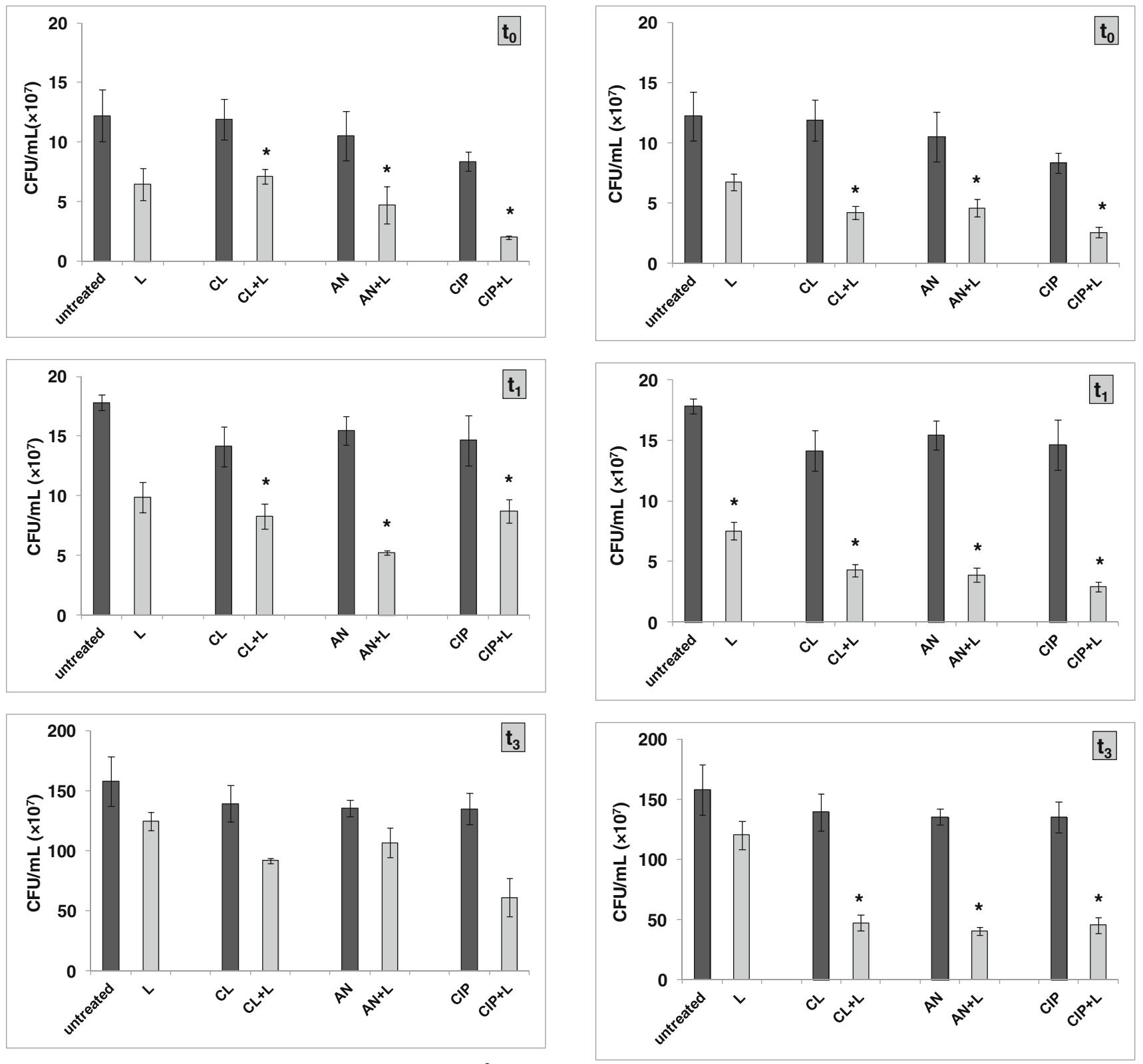

Fig. 4 Effect of PDT (Ce6 $50 \mu \mathrm{g} / \mathrm{mL}$; energy dose $120 \mathrm{~J} / \mathrm{cm}^{2}$ ) on the survival of Escherichia coli treated with antibiotics. Untreated, no antibiotic, no irradiation; L, light; CL, colistin; AN, amikacin; CIP, ciprofloxacin. Values represent the mean $\pm \mathrm{SD}$ of three separate experiments. The asterisk indicates a statistically significant result $(p<0.05)$

Ce6 is moderately hydrophobic; therefore, it shows the affinity to lipid-containing cell structures. It seems, however, that it was not able to penetrate the wellorganized outer envelope of gram-negative bacteria, accumulate inside in a large enough amount, and exert a bactericidal effect when used alone. This can be deduced by comparing "untreated" and "L" bars in Figs. 2, 3, 4, and 5. Since antibiotics were used in sub-MIC concentrations, they also showed no bacteriakilling effect.

Fig. 5 Effect of PDT (Ce6 $100 \mu \mathrm{g} / \mathrm{mL}$; energy dose $120 \mathrm{~J} / \mathrm{cm}^{2}$ ) on the survival of Escherichia coli treated with antibiotics. Untreated, no antibiotic, no irradiation; L, light; CL, colistin; AN, amikacin; CIP, ciprofloxacin. Values represent the mean $\pm \mathrm{SD}$ of three separate experiments. The asterisk indicates a statistically significant result $(p<0.05)$

Analysis of the obtained results showed that when antibiotics and aPDT were used together, they showed remarkable antibacterial activities (Figs. 2, 3, 4, and 5). Moreover, their combined antimicrobial effect was dependent on the PDT conditions. The most profound effects were achieved for Ce6 at a concentration of $100 \mu \mathrm{g} / \mathrm{mL}$ and the energy dose $120 \mathrm{~J} / \mathrm{cm}^{2}$ (Fig. 5). It is worth noticing that under these experimental conditions, a significant reduction of bacterial survival was observed even after $3 \mathrm{~h}$ from irradiation (Fig. 5). Such prolongation of antibacterial effect was not observed in any 
other experimental protocol used (Figs. 2, 3, and 4). Such a promising antibacterial effect was achieved due to the combined action of the antibiotic and the excited photosensitizer. Our experiments have shown, however, that the effects obtained for three antibiotic/Ce6 combinations were somehow different, depending on the kind of antibiotic used. The best antigrowth effect of aPDT was noticed for bacterial samples treated with CIP (Fig. 5). Presumably, this phenomenon results from the oxidative damage of DNA by PDT and the inhibition of bacterial gyrase by CIP, in both cases resulting in the impairment of the DNA replication $[8,9]$. The enhancement of the antibacterial activity of antibiotic by PDT was also observed in E. coli suspensions treated with CL (Fig. 5). The mechanism of CL activity is connected with the interactions of its cationic polypeptide ring and the anionic phosphate groups present in the cell membrane of the gram-negative bacteria [9]. These interactions cause the displacement of $\mathrm{Ca}^{2+}$ and $\mathrm{Mg}^{2+}$ ions increasing cell membrane permeability leading to the leakage of bacterial cell contents. Reactive oxygen species generated during PDT are responsible for the bacterial cell membrane disruption and therefore can enhance the antimicrobial effect of CL [8]. The weakest, but also statistically significant, combined effect of PDT and antibiotics was noticed in the case of UPECs exhibited to AN (Fig. 5). AN impairs the process of protein synthesis by inhibition of small ribosomal subunits. It is not directly connected with the main targets (DNA, cell membranes) of reactive oxygen species generated during photodynamic reactions $[8,9]$. It seems, therefore, that aPDT better enhances the activity of CIP and CL than AN. Recently, the effects and mechanisms of combined antibiotics and aPDT action have been described $[25-30,37,38]$. One of them is the work of Ronqui et al. [26], who described the synergistic effect of aPDT and CIP against E. coli and Staphylococcus aureus growing in planktonic and biofilm cultures. The results were significant when CIP was administered before the aPDT treatment as well as when the CIP administration was followed by an aPDT. In the case of both bacterial species, the number of colony-forming unites per milliliter was reduced; however, gram-positive bacteria were more susceptible to PDT than gram-negative ones, which is consistent with other literature [29, 31]. Another study of combining aPDT with two fluoroquinolones (CIP and norfloxacin) was presented by Pereira et al. [29]. This study demonstrated that irradiation of E. coli and $S$. aureus with blue or red light in the presence of CIP is more effective than antibiotic monotherapy. A similar result was also obtained with the combined use of aPDT and norfloxacin. Another interesting application of combining aPDT and antibiotic treatment was described by Boluki et al. [38]. They used aPDT and CL against pan-drug-resistant Acinetobacter baumannii strain. The obtained results showed that the application of aPDT resulted in increased bacterial drug susceptibility. The authors found that the expression of the $p m r A$ and $p m r B$ genes, which are responsible for the synthesis of lipid A - strictly linked with resistance to CL-was lower than in untreated cells. These results may suggest a mechanism underlying the synergy between antimicrobials and light therapy. One more interesting and valuable research was conducted by Pourhajibagher et al. [37]. They evaluated the efficacy of aPDT in combination treatment with $\mathrm{CL}$ against pan-drugresistant $A$. baumannii and found that combined therapy eliminated bacteria in all tested CL concentrations.

Taken together, our results showed that aPDT using Ce6 improves the antibacterial activity of antibiotics effectively inhibiting bacterial growth and being promising in the elimination of bacterial urinary infections in humans.

Funding information This work was supported by the Wroclaw Medical University Grant No. ST.A060.16.024.

\section{Compliance with ethical standards}

Conflict of interest The authors declare that they have no conflict of interest.

Open Access This article is distributed under the terms of the Creative Commons Attribution 4.0 International License (http:// creativecommons.org/licenses/by/4.0/), which permits unrestricted use, distribution, and reproduction in any medium, provided you give appropriate credit to the original author(s) and the source, provide a link to the Creative Commons license, and indicate if changes were made.

Publisher's note Springer Nature remains neutral with regard to jurisdictional claims in published maps and institutional affiliations.

\section{References}

1. Firoozeh F, Saffari M, Neamati F, Zibaei M (2014) Detection of virulence genes in Escherichia coli isolated from patients with cystitis and pyelonephritis. Int J Infect Dis 29:219-222

2. Wagenlehner FME, Wullt B, Perletti G (2011) Antimicrobials in urogenital infections. Int J Antimicrob Agents 38:3-10

3. Bonkat G, Widmer AF, Rieken M, van der Merwe A, Braissant O, Müller G, Wyler S, Frei R, Gasser TC, Bachmann A (2013) Microbial biofilm formation and catheter-associated bacteriuria in patients with suprapubic catheterization. World J Urol 31:565-571

4. O'Neill J (2016) Tackling drug-resistant infections globally: final report and recommendations. The review on antimicrobial resistance. HM Government \& Wellcome Trust, London

5. Logan LK (2012) Carbapenem-resistant Enterobacteriaceae: an emerging problem in children. Clin Infect Dis 55:852-859

6. Park JH, Moon YH, Bang IS, Kim YC, Kim SA, Ahn SG, Yoon JH (2010) Antimicrobial effect of photodynamic therapy using a highly pure chlorin e6. Lasers Med Sci 25:705-710

7. Tanaka M, Kinoshita M, Yoshihara Y, Shinomiya N, Seki S, Nemoto K, Hirayama T, Dai T, Huang L, Hamblin MR, Morimoto Y (2012) Optimal photosensitizers for photodynamic therapy of infections should kill bacteria but spare neutrophils. Photochem Photobiol 88:227-232 
8. Wozniak A, Grinholc M (2018) Combined antimicrobial activity of photodynamic inactivation and antimicrobials-state of the art. Front Microbiol 9:930

9. Kapoor G, Saigal S, Elongavan A (2017) Action and resistance mechanisms of antibiotics: a guide for clinicians. J Anaesthesiol Clin Pharmacol 33:300-305

10. Maisch T (2015) Resistance in antimicrobial photodynamic inactivation of bacteria. Photochem Photobiol Sci 14:1518-1526

11. Ryu AR, Wang YY, Lee MY (2014) Differential protein expression associated with photodynamic therapy using chlorin e6. Mol Cell Toxicol 10:423-431

12. Park H, Na K (2013) Conjugation of the photosensitizer chlorin e6 to pluronic F127 for enhanced cellular internalization for photodynamic therapy. Biomaterials 34:6992-7000

13. Liu S, Qiao S, Li L, Qi G, Lin Y, Qiao Z, Wang H, Shao C (2015) Surface charge-conversion polymeric nanoparticles for photodynamic treatment of urinary tract bacterial infections. Nanotechnology 26(49):495602

14. Huang YY, Wintner A, Seed PC, Brauns T, Gelfand JA, Hamblin MR (2018) Antimicrobial photodynamic therapy mediated by methylene blue and potassium iodide to treat urinary tract infection in a female rat model. Sci Rep 8:7257

15. Bonkat $G$, Pickard R, Bartoletti R, Bruyère F, Geerlings SE, Wagenlehner F, Wullt B, Cai T, Köves B, Pilatz A, Pradere B, Veeratterapillay R (2017) Guidelines on urological infections. In: EAU guidelines European Association of Urology

16. Falagas ME, Kasiakou SK (2005) Colistin: the revival of polymyxins for the management of multidrug-resistant gram-negative bacterial infections. Clin Infect Dis 40:1333-1341

17. Falagas ME, Grammatikos AP, Michalopoulos A (2008) Potential of old-generation antibiotics to address current need for new antibiotics. Expert Rev Anti-Infect Ther 6:593-600

18. Jiménez-Guerra G, Heras-Cañas V, Gutiérrez-Soto M, Del Pilar Aznarte-Padial M, Expósito-Ruiz M, Navarro-Marí JM, Gutiérrez-Fernández J (2018) Urinary tract infection by Acinetobacter baumannii and Pseudomonas aeruginosa: evolution of antimicrobial resistance and therapeutic alternatives. J Med Microbiol 67:790-797

19. Karakkattu J, Mohan A, James E, Kumar A (2017) Effectiveness and safety of colistin in multidrug-resistant urinary tract infections. J Appl Pharm Sci 7:148-152

20. Clinical and Laboratory Standards Institute (CLSI) (2017) Performance standards for antimicrobial susceptibility testing; twenty-seventh informational supplement (M100-S27). Wayne, PA, USA

21. Babilas P, Szeimies RM (2010) The use of photodynamic therapy in dermatology. G Ital Dermatol Venereol 145:613-630

22. Kumar V, Sinha J, Verma N, Nayan K, Saimbi CS, Tripathi AK (2015) Scope of photodynamic therapy in periodontics. Indian J Dent Res 26:439-442

23. Lang GE, Mennel S, Spital G, Wachtlin J, Jurklies B, Heimann H, Damato B, Meyer CH (2009) Different indications of photodynamic therapy in ophthalmology. Klin Monatsbl Augenheilkd 226:725739 [in German]

24. Lee HH, Choi M-G, Hasan T (2017) Application of photodynamic therapy in gastrointestinal disorders: an outdated or re-emerging technique? Korean J Intern Med 32:1-10
25. Pérez-Laguna V, Pérez-Artiaga L, Lampaya-Pérez V, García-Luque I, Ballesta S, Nonell S, Paz-Cristobal MP, Gilaberte Y, Rezusta A (2017) Bactericidal effect of photodynamic therapy, alone or in combination with mupirocin or linezolid on Staphylococcus aureus. Front Microbiol 8:1002

26. Ronqui MR, de Aguiar Coletti TM, de Freitas LM, Miranda ET, Fontana CR (2016) Synergistic antimicrobial effect of photodynamic therapy and ciprofloxacin. J Photochem Photobiol B 158: $122-129$

27. Fila G, Kawiak A, Grinholc MS (2016) Blue light treatment of Pseudomonas aeruginosa: strong bactericidal activity, synergism with antibiotics and inactivation of virulence factors. Virulence 8: 938-958

28. Jeong S, Lee J, Im BN, Park H, Na K (2017) Combined photodynamic and antibiotic therapy for skin disorder via lipase-sensitive liposomes with enhanced antimicrobial performance. Biomaterials 141:243-250

29. Pereira NLF, Aquino PEA, Júnior JGAS, Cristo JS, Vieira Filho MA, Moura FF, Ferreira NMN, Silva MKN, Nascimento EM, Correia FMA, Cunha FAB, Boligon AA, Coutinho HDM, Ribeiro-Filho J, Matias EFF, Guedes MIF (2017) Antibacterial activity and antibiotic modulating potential of the essential oil obtained from Eugenia jambolana in association with led lights. J Photochem Photobiol B 174:144-149

30. Choi S, Lee H, Yu J, Chae H (2015) In vitro augmented photodynamic bactericidal activity of tetracycline and chitosan against Clostridium difficile KCTC5009 in the planktonic cultures. J Photochem Photobiol B 153:7-12

31. Huang L, Zhiyentayev T, Xuan Y, Azhibek D, Kharkwal GB, Hamblin MR (2011) Photodynamic inactivation of bacteria using polyethylenimine-chlorin(e6) conjugates: effect of polymer molecular weight, substitution ratio of chlorin(e6) and $\mathrm{pH}$. Lasers Surg Med 43:313-323

32. Wojnicz D, Tichaczek-Goska D, Kicia M (2013) Effect of asiatic and ursolic acids on growth and virulence factors of uropathogenic Escherichia coli strains. Turk J Biol 37:556-564

33. Cunderlíková B, Gangeskar L, Moan J (1999) Acid-base properties of chlorin e6: relation to cellular uptake. J Photochem Photobiol B 53:81-90

34. Drulis-Kawa Z, BednarkiewiczA BG, Stręk W, Doroszkiewicz W (2006) Bactericidal effects of the Fotolon (chlorin e6) on gramnegative and gram-positive strains isolated from wound infections. Adv Clin Exp Med 15:279-283

35. Jeon YM, Lee HS, Jeong D, Oh HK, Ra KH, Lee MY (2015) Antimicrobial photodynamic therapy using chlorin e6 with halogen light for acne bacteria-induced inflammation. Life Sci 124:56-63

36. Kaczmarska L, Jakoniuk P (2003) Therapeutic effect of some antibiotics on experimental staphylococcal infection and its correlation with the activity in sub-inhibitory concentrations against Staphylococcus aureus strains. Med Dosw Mikrobiol 55:1-10 [in Polish]

37. Pourhajibagher M, Kazemian H, Chiniforush N, Bahador A (2017) Evaluation of photodynamic therapy effect along with colistin on pan-drug-resistant Acinetobacter baumannii. Laser Ther 26:97-103

38. Boluki E, Kazemian H, Peeridogaheh H, Alikhani MY, Shahabi S, Beytollahi L, Ghorbanzadeh R (2017) Antimicrobial activity of photodynamic therapy in combination with colistin against a pandrug resistant Acinetobacter baumannii isolated from burn patient. Photodiagn Photodyn Ther 18:1-5 